Doi: https://doi.org/10.17398/2340-4256.15.221

\title{
RESTITUTION AND CORRECTIVE JUSTICE IN THE ARISTOTELIAN SCHOLASTIC TRADITION: THE CONTRIBUTION OF FRANCISCO SUÁREZ (1548-1617)*
}

\author{
RESTITUCIÓN Y JUSTICIA CORRECTIVA EN LA TRADICIÓN \\ ARISTOTÉLICA ESCOLÁSTICA: EL APORTE DE FRANCISCO \\ SUÁREZ (1548-1617)
}

SEBASTIÁn CONTRERAS AgUIRRE

Universidad de los Andes, Chile

Recibido: 05/11/2019

Aceptado: 22/12/2019

\begin{abstract}
This article examines the concept of corrective justice in the Aristotelian Scholastic tradition, with a particular focus on the philosophy of Francisco Suárez. Despite the value of restitution in classical legal theory, corrective justice cannot be defined as a merely restorative virtue. The Aristotelian Scholastic tradition assigns to it other important objectives, such as the establishment of the equivalence in contractual benefits, the fulfillment of agreements in good faith, and the respect for other people's rights. Suárez, unlike the rest of the scholastics, has examined with great attention the

\footnotetext{
* This article was financed and supported by the FONDECYT-Chile grant 1180510, and the FAI research grant provided by Universidad de los Andes. The author wishes to thank professors Alexander Fidora, Christian Schäfer and Joaquín García-Huidobro for their commentaries and advice.

This paper is also part of a broader research on the legal theory of Second Scholasticism directed by the Prof. Caridad Velarde of Universidad de Navarra, Spain.
} 
nonrestitutive aspect of the commutative justice. In his proposal, corrective justice fulfills an institutive and directive function in private dealings. According to Suárez, a virtue with those characteristics doubtlessly exceeds the ambit of reparation.

Keywords: Aristotle, corrective justice, Francisco Suárez, restitution, synállagma/ synallágmata, unfair enrichment.

\section{RESUMEN}

Este trabajo estudia el concepto de justicia correctiva de la tradición aristotélica escolástica, centrándose especialmente en la filosofía de Francisco Suárez. Más allá del valor que tiene la restitución en la teoría jurídica de los autores clásicos, lo justo correctivo no puede definirse solo por su aspecto reparatorio. La tradición aristotélica escolástica confiere a la justicia correctiva otros fines más importantes, como el establecimiento de la equivalencia de las prestaciones contractuales, el cumplimiento de buena fe de los actos y contratos, así como el respeto de los derechos de los demás. Suárez, a diferencia del resto de los escolásticos, ha examinado con atención el aspecto no restitutorio de lo justo conmutativo. Como se verá, para Suárez la justicia correctiva, que tiene una función instituyente y directiva en las conmutaciones, excede con mucho el ámbito de la reparación.

Palabras clave: Aristóteles, enriquecimiento injusto, Francisco Suárez, justicia correctiva, restitución, synállagma/synallágmata.

\section{INTRODUCTION}

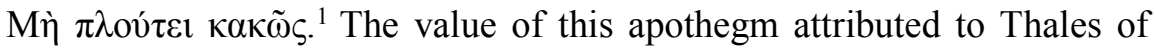
Miletus -who was allegedly the greatest of the Seven Sages- is not only historically, but also philosophically significant. It is safe to say that this maxim synthetizes classical ethics. Under the concept of classical ethics, I understand that moral theory which is rooted in Aristotle's works, was subsequently developed by Albertus Magnus, Thomas Aquinas, John Duns Scotus and their followers, and which reached its culmination in the philosophical project of the Second Scholasticism.

1 'Do not get wealth in a bad way'. Georg Wöhrle (ed.), The Milesians: Thales (Berlin: W. de Gruyter, 2014), Th $362 / 313$. 
The apothegm warns against pleonexia $\left(\pi \lambda \varepsilon \mathrm{ov} \varepsilon \xi \xi^{\prime} \alpha\right)$, i.e. the excessive greed for wealth, the cause of many ills, which was described by Greek philosophers as an obstacle to justice. ${ }^{2}$ Indeed, if justice is a 'virtue', a 'proportion', and an 'equality', pleonexia is, on the contrary, a 'vice', an 'excess', and an 'abuse'. Thales' axiom is equivalent to the precept that forbids unjust enrichment. ${ }^{3}$

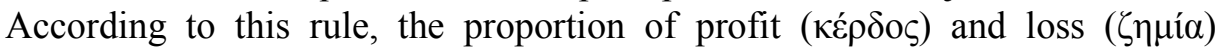

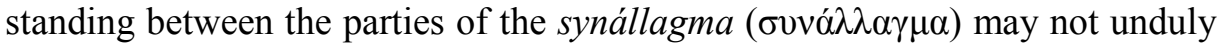
harm anyone. ${ }^{4}$ It is proper of corrective justice to guarantee reciprocity, to prevent illicit gains, to institute the specific equality of commutations, and to prevent pleonexia. According to classical thinkers, corrective justice is the quintessence of the cardinal virtue of justice, for it gives each strictly their own. This kind of justice has mainly a constructive function: it renders man good, ${ }^{5}$ it renders him praiseworthy, ${ }^{6}$ it renders his works good. ${ }^{7}$ In the terms of Francisco Suárez, although corrective justice is a kind of remedy for inequality, it is, first and foremost, a rule that orders acts and arranges contracts. This is how the socalled Eximius puts it in his still unpublished commentary on Aristotle's Ethica. ${ }^{8}$

Pleonexia involves more than the insatiable greed for profit; "it also includes a desire to have more than I am entitled to [...] so as to get the better of someone else." As to the meaning of pleonexia in Aristotle's philosophy, T. Irwin remarks that protecting people from the harm derived from ambition is the hallmark of corrective justice. ${ }^{10} \mathrm{O}$. Höffe argues that the concepts of

2 Plato, Symposium (New Haven/London: Yale University Press, 1991), 188a-c.

3 The 'do not get wealth in a bad way' maxim is also equivalent to other equity principles such as 'thou shall not harm anyone' (Ulpian, Digesta Iustiniani), or 'love thy neighbor as thyself' (Leviticus), or 'no one shall wrongfully enrich himself to the prejudice of another' (Alfonso of Castile, Partidas), or 'render to each their due' (Cicero, De officiis), or 'no one ought to profit by the loss of another' (Gaius, Digesta Iustiniani), or 'to do one's own work' (Plato, Respublica), or 'do not plot harm against your neighbor' (Liber proverbiorum), or 'flee from pleonexia' (Luis de León, De gratia et iustificatione), etc.

4 Aristotle, Ethica Nicomachea, trans. Terence Irwin (Indianapolis: Hackett, 2019), E 4 §6-14 (unless otherwise indicated, subsequent citations are taken from this edition); Magna moralia (Cambridge/London: Harvard University Press, LCL 287, 1935), A 33 §§4-7.

5 Aristotle, Ethica Nicomachea, B 1 §7.

6 Aristotle, Artis rhetorica (Cambridge/New York: Cambridge University Press, 2009), A 9 §6; Ethica Eudemia (Cambridge/New York: Cambridge Uuniversity Press, 2013), B 1 §19; Topica (Cambridge/London: Harvard University Press, LCL 391, 1960), B 9. In Aristotle's words, "if justice is something praiseworthy, then the just man and the just action... will be something praiseworthy" (ibid.).

7 Aristotle, Ethica Nicomachea, $\Delta 7$ §7; E 1 §3; E 5 §17; K 3 §2; Magna moralia, A 33 §§4-7; A 33 §22; Ethica Eudemia, B 1 §19.

8 Francisco Suárez, Commentarii in Ethica Aristotelis (Bibliothèque Nationale de France, cod. lat. $6775,1585)$, ff. $84 \mathrm{r}-87 \mathrm{v}, 100 \mathrm{v}-105 \mathrm{r}$.

9 Terence Irwin, "Glossary”, in Aristotle, Nicomachean Ethics (Indianapolis: Hackett, 20193), 388.

10 Terence Irwin, Aristotle’s First Principles (Oxford: Clarendon Press, 2002), 429. 
'commutative justice' and 'pleonexia' go beyond the economic sphere. ${ }^{11}$ That is certainly the case. According to the writings of Aristotle and Suárez, the pleonectic desire induces wrongs to honor and safety -not only patrimonial damages. $^{12}$

Suárez uses the terms 'loss', 'profit', 'obligation to repair', and 'equality' among others-, to signify the injustice of murder, to explain the duty of restitution of the bribed official, to object to the denial of the agnatic rights, etc. The Eximius, like Aristotle, thinks that any grievance entails a gain. Hence, a defamation, an unfair attack or the abuse of the employee always makes the offender richer. The offender becomes richer because he satisfies his disorderly desire. Consequently, whoever acts in pursuit of his individual interest and injures others, gains something and is unjustly enriched. To gain, then, means to fulfill one's desire. ${ }^{13}$ In this sense, whoever harms another to achieve their own goals gains by doing or getting something he or she wants, or by trying to do so. Thence, this person is obliged to restitute. ${ }^{14}$ Francisco Suárez knows that the concept of 'profits' derives from civil affairs, but he understands that the scope of pleonexia exceeds the margins of patrimony. ${ }^{15}$

Suárez's elucidations of the nature of restitution predate the work of Hugo de Groot, who is hailed as the architect of the theory of illicit enrichment. ${ }^{16}$ Suárez's theory on particular justice sets in order the ideas of the other scholastics, fills Aristotle's intuitions with legal content, and lays the foundations of the modern Law of Torts, in which, as E. Weinrib wrote, each contravention of corrective justice implies one party's gain at the other's expense. ${ }^{17}$

This paper does not intend to address all aspects of the scholastic doctrine of restitution. It seeks to clarify the nature of corrective justice and the categories of 'illicit gain' and 'restitution' in the authors of the Second Scholasticism, especially in Suárez's philosophy, insofar as they interpret the Stagirite's moral

11 Otfried Höffe, Gerechtigkeit. Eine philosophische Einführung (München: Beck, 2007), 11-12; Political Justice (Cambridge: Polity Press, 1995), 190-ss; Democracy in an Age of Globalisation (Dordrecht: Springer, 2007), 35-60.

12 Aristotle, Ethica Nicomachea, E 2 §6; Francisco Suárez, De iustitia Dei (Opera omnia, v. XI, Paris: Vivès, 1858), s. II, nn. 1-7, 18-23; Commentarii in Ethica Aristotelis, ff. 100v-105r.

13 James Gordley, "The Moral Foundations of Private Law", The American Journal of Jurisprudence 47/1 (2002): 10-13.

14 Gordley, "The Moral Foundations of Private Law", 12.

15 Francisco Suárez, Defensio fidei (Conimbricæ, 1613), 1. IV, c. 23, n. 6.

16 Helmut Coing, Europäisches Privatrecht. Älteres Gemeines Recht (1500 bis 1800) (München: Beck, 1985), 191.

17 Ernest Weinrib, The Idea of Private Law (Oxford: Oxford University Press, 2012), 63. 
theory. With that in view, this article has been divided as follows. In the first place, it explains that reparation does not exhaust the ordering function of corrective justice. Secondly, it describes the meaning of the concepts of restitution and synallágmata in Aristotle's writings. Thirdly, it presents, in general terms, the Suárezian doctrine on corrective justice, to end with the analysis of the Scholastic and Suárezian understanding of restitution.

\section{THE CORRECTIVE JUST AND THE DUTY OF RESTITUTION IN THE ARISTOTELIAN SCHOLASTIC TRADITION}

The writings of Suárez and other classical thinkers -Michael Ephesius, Thomas Aquinas, Francisco de Vitoria, Domingo de Soto, Juan de la Peña, Melchor Cano, Pedro de Aragón, etc.-, testify to the restitutive interpretation of corrective justice within the classic tradition. ${ }^{18}$ Despite their reparative emphasis, Suárez, Aristotle or Aquinas probably thought that the corrective just transcends the mere compensation. In contrast with them, several scholastics and many other interpreters of the Stagirite have wrongly reduced commutative justice to a virtue aimed at the reparation of the damages derived from contracts.

Among the scholastics, Salamanca professor Fernando de Roa paradigmatically instantiates this reading of Aristotle. He holds that this virtue corrects (corrigere) breached obligations and contracts. ${ }^{19} \mathrm{I}$ do not intend to excuse Roa, yet, Aristotle's use of some concepts (e.g., 'harm', 'inequality', 'victim', when discussing the act by which someone kills and someone $\operatorname{dies}^{20}$ ) partially justifies the exclusively reparative significance given to this virtue. The rectifying vision of corrective justice has been defended too by contemporary authors like F. Ricken, D. Ross, C. Despotopoulos, A. Kaufmann, F. Miller and

18 Francisco Suárez, De legibus ac Deo legislatore (Conimbricæ, 1612), 1. V, c. 11, n. 4; Qucestiones de iustitia et iure (Freiburg: Herder, 1958), d. IV, q. 8, f. 51v; Michael of Ephesus, In IX Ethicorum (London: Bloomsbury, 2001), 1164b6-9; Thomas Aquinas, Summa theologice (New York: Benziger Bros, 1947), II-II q. 62 a. 1; Francisco de Vitoria, De iustitia: De restitutione (Stuttgart: Frommann-Holzboog, 2017), q. 62 a. 1; Domingo de Soto, De iustitia et iure (Madrid: IEP, 1967-1968), IV.vi.1; De iustitia (ms. ott. lat. 781, Vatican Library), q. 62 a. 1; Juan de la Peña, De iustitia (ms. 1852, General Library of the University of Coimbra), q. 62 a. 1; Melchor Cano, De locis theologicis (Roma: Libreria Editrice della Vera Roma di E. Filiziani, 1900), X.viii; Pedro de Aragón, De iustitia et iure (Salmanticæ, 1590), q. 62 a. 1. As a rule, late-scholastic authors do nothing more than repeat the Thomist definition of restitution as an exclusive act of corrective justice. However, because in a certain way to restitute means to equalize, and because establishing equality is what all acts of justice seek, the Dominicans Mancio de Corpus Christi and Domingo Báñez extend restitution to the other mode of particular justice. Vid. Mancio de Corpus Christi, De iure et iustitia (Pamplona: Eunsa, 2013), q. 59 a. 3, f. 549r; Domingo Báñez, De iure et iustitia decisiones (Salamanticæ, 1594), q. 58 a. 7.

19 Fernando de Roa, Repetitio de justitia et injustitia (Salamanca: Universidad Pontificia de Salamanca, 2007), f. 7.

20 Aristotle, Ethica Nicomachea, E 4 §4. 
A. MacIntyre, who end up restricting the Aristotelian idea of the commutative just to the act of reparation. ${ }^{21}$

In its rectifying version, this virtue "looks only to the [...] injury" and encloses "a bipolar conception of injustice as a violation of quantitative equality [...] and a bipolar conception of the remedy as the annulment of the parties' correlative gain and loss." 22 Simultaneously, 'remedial justice', as it is also called, ${ }^{23}$ "includes a reference to the status of the parties and the voluntariness or involuntariness of the act; it takes account of 'moral and intellectual damages' as well as of physical or financial injury." 24 It is added that corrective justice is that which "rectifies or remedies inequalities which arise in dealings [...] between individuals." ${ }^{25}$ Thereby, it is defined as the virtue that only heeds the damage and its restoration. ${ }^{26}$ Now, paraphrasing Aristotle, it has been written that "corrective justice [...] covers the whole sphere of what we should call civil and criminal." 27 Thus, as Höffe points out, this justice "is in turn subdivided into a 'voluntary sector', that is, what is now called civil law [...] and an 'involuntary sector', or what we call criminal law." 28

J. Pieper supports an extremely restorative reading of the commutative just, far more radical than Roa's position. Pieper constructs his explanation of corrective justice around the assumption that the act of this virtue is restitution (not without first criticizing a certain doctrine which, in his opinion, attempts to weaken the value of this theorem). ${ }^{29}$ To my mind, Pieper's approach, which rules out any corrective act other than restitution, ${ }^{30}$ contradicts the most basic

21 Friedo Ricken, “Aristoteles und die moderne Tugendethik”, in Gemeinschaft, Tugend, Glück, ed. F. Ricken (Stuttgart: Kohlhammer, 2004), 127-139; David Ross, Aristotle (London/New York: Routledge, 2005), 220; Constantin Despotopoulos, "La notion de synallagma chez Aristote", Archives de philosophie du droit 13 (1968): 115-127; Arthur Kaufmann, Rechtsphilosophie (München: Beck, 1997), 157-158; Fred D. Miller, Nature, Justice, and Rights in Aristotle's Politics (Oxford/New York: Clarendon Press, 1995), 71-74; Alasdair MacIntyre, A Short History of Ethics (London: Routledge, 1998), 79; Whose Justice? Which Rationality? (Notre Dame: University of Notre Dame Press, 1988), 103-123.

22 Ross, Aristotle, 220; Weinrib, The Idea of Private Law, 65-66.

23 Ross, Aristotle, 220; Frederick Copleston, A History of Philosophy: Greece and Rome (New York/London: Image, 1993), 342; Max Hamburger, Morals and Law. The Growth of Aristotle's Legal Theory (New York: Biblo \& Tannen, 1971), 43-ss.

24 Ross, Aristotle, 220.

25 John Finnis, Natural Law and Natural Rights (Oxford: Oxford University Press, 2011), 178.

26 Luís G. Soto, Teoría de la justicia e idea del derecho en Aristóteles (Madrid/Barcelona: Marcial Pons, 2011), 328 .

27 Ernest Barker, The Political Thought of Plato and Aristotle (New York: Dover, 1959), 343.

28 Otfried. Höffe, Aristotle (Albany: State University of New York Press, 2003), 157.

29 Josef Pieper, The Four Cardinal Virtues (New York: Harcourt, Brace \& World, 1965), 76-80.

30 Pieper, The Four Cardinal Virtues, 78. 
rules of internal coherence with which any theory on particular justice must comply.

In line with Aristotle and St. Thomas, Pieper holds that the differences between the modes of partial justice-viz., the justice that directs the distribution of common goods and the justice that regulates commutations between private individuals - fail to draw any real distinction between these subclasses of the virtue of justice, because, despite their dissimilarities, both are ordered to the good of private individuals. Moreover, both corrective and distributive justice fall within what Aristotle identifies as the habit that deals with honor, money and security. ${ }^{31}$ Likewise, both types of justice coincide in the ideal of equity and in the kind of opposed injustice, namely, the injury that proceeds from pleonexia. ${ }^{32}$ Hence, because "injustices in the political community (e.g., acts of violence, robberies, and the like) happen because of the love of honor and money," 33 Aquinas writes that

[...] particular justice $<$ not only $>$ regards those things that take into account social intercourse, like honor, money, whatever pertains to the safety or harm to the body, and so on $[\ldots]<$ but it also considers $>$ pleasure consequent on the profit by which a man takes his neighbor's goods beyond what he ought. ${ }^{34}$

Even though Pieper describes distributive and corrective justice as forms of the same virtue, i.e. the justice that gives to particular subjects their due, ${ }^{35}$ he does not define the acts of these kinds of partial justice according to the structure of two species within the same genus. According to Pieper's account -and to the rectifying interpretation of Aristotle in general-, whereas the geometric just consists in the distribution that follows the criteria of necessity and merits, the arithmetic just consists in the mere reparation of illicit enrichment. ${ }^{36}$ The argumentative imbalance is apparent. What is just in distributions has a 'constructive' and 'positive' attribute, insofar it renders man and his actions good, like the other virtues of character; why should the arithmetical just have, in contrast to the distributive just, only a 'negative' quality that supposes the reestablishment of the state of equality that existed before the injury? It could even

31 Aristotle, Ethica Nicomachea, E 2 \$6.

32 Aristotle, Ethica Nicomachea, E $1 \S 8$; E2 $\S \S 1-11$. "From the beginning, Aristotle associates particular injustice with pleonexia -variously, greed, the desire to have more, the desire to have more than others". Bernard Williams, The Sense of the Past (New Jersey: Princeton University Press, 2006), 207.

33 Thomas Aquinas, Sententia libri Politicorum (Indianapolis: Hackett, 2007), II.xiv.

34 Thomas Aquinas, Sententia libri Ethicorum (Notre Dame: Dumb Ox Books, 1993), n. 919.

35 Pieper, The Four Cardinal Virtues, 71.

36 Pieper, The Four Cardinal Virtues, 70-103. Similarly: Miller, Nature, Justice, and Rights in Aristotle's Politics, 73n; Weinrib, The Idea of Private Law, 56-ss; José Carlos Muinelo, La invención del derecho en Aristóteles (Madrid: Dykinson, 2011), 75-77. 
be argued that, if the vice of both types of justice consists of the same thing -i.e. the "special injustice $<$ which $>$ is concerned with honour or wealth or safety [...] and $<$ that $>$ aims at the pleasure that results from making a profit" $" 37$, the act of these modes of virtue should match. Suárez supports this identification by saying that the act of the two kinds of particular justice is always an act of direction (since it is proper of partial justice, in one case, to direct the distributions, and, in the other, to direct the commutations). ${ }^{38}$

J. Finnis criticizes the rectifying reading of the corrective just (truly, Finnis criticizes Aristotle's explanation of the commutative just). He maintains that the strict virtue of giving each their due is neither simply restitutive nor is it indifferent with respect to the obligation to repair the damages to third parties; more precisely, corrective justice governs all dealings that can take place in the vast field of human interaction. ${ }^{39}$ This account is conceptually limited by the subjection of correction to the principle of equality in recompense, which is, Finnis says, "the guiding principle in all voluntary and non-voluntary transactions." 40

Anyhow, this is not a novelty of Finnis' theory of justice. Suárez had already warned that corrective justice, as a true virtue, is defined more properly by its constructive quality than by its reparative dimension (over and above the duty to return goods, the duty to observe in conscience the rights of others is proper to corrective justice ${ }^{41}$ ). Thereby, Suárez remarks in the Tractatus quartus that this "is the justice standing among private persons," ${ }^{42}$ who are obviously related not only through the injury. Suárez adds there that the corrective just is defined firstly by its constituent character: it renders commutations righteous. ${ }^{43}$ Suárez did not come up with this doctrine. Medieval and Premodern Scholastics had already discussed it at length.

37 Aristotle, Ethica Nicomachea, E 2 \$6.

38 Francisco Suárez, Qucestiones de iustitia et iure, d. IV, q. 3, f. 40r.

39 J. Finnis, Natural Law and Natural Rights, 179.

40 John Finnis, Aquinas (Oxford: Oxford University Press, 1998), 201n. Similarly, it is said that commutative acts should be subject to the principle of proportional share in profits and losses. Norbert Brieskorn, Rechtsphilosophie (Stuttgart: Kohlhammer, 1990), 94.

41 On this regard, see Joseph Mausbach \& Gustav Ermecke, Katholische Moraltheologie. Die spezielle Moral: Der irdische Pflichtenkreis (Münster: Aschendorff, 1961), 134. Furthermore, it is also an act of corrective justice to promote the welfare of other individuals. In this context, some teach that this virtue has a clear social dimension. For instance, see Otto von Gierke, "The Social Role of Private Law", German Law Journal 19/4 (2018): 1017-1116.

42 Francisco Suárez, Tractatus quartus (Opera omnia, v. IV, Paris: Vivès, 1856), d. III, s. 4, n. 4.

43 Francisco Suárez, De iustitia Dei, s. II, n. 7. 
Aquinas, for example, teaches that corrective justice "directs commutations that can take place between two persons." "44 Alonso de la Veracruz, the so-called protector of the Indians, ${ }^{45}$ maintains that "in the buying and selling, commutative justice is present, provided that neither fraud nor deceit intervenes." ${ }^{46}$ Regarding the contracts of sale and purchase signed between Indians and Spaniards, this disciple of Vitoria adds that, because these are legitimate businesses, "this justice is present in them." ${ }^{\text {" }}$ He thus highlights what could be understood as the extra-restitutive aspect of this virtue, which explains the regulatory function that corrective justice has in all private relations -and not only in view of offenses and defrauded agreements. Therefore, far from being limited to restitution, this justice will be defined by its ability to render deals and contracts compulsory. ${ }^{48}$ Dealings will be valid as synallagmatic nexuses only when the desired equivalence of commuted things has been achieved, as Francisco García formulates it. ${ }^{49}$

Finally, Juan de Zapata y Sandoval holds, on the one hand, that the ordering principle of the corrective just "concerns human coexistence," ${ }^{50}$ and, on the other hand, that commutative justice, which guides contractual activity, ${ }^{51}$ "establishes the [...] rectitude of exchanges and other businesses." 52 To affirm that this justice concerns human coexistence underlines the necessity of the transactions and other commutations for human flourishing. From this background, Pedro de Oñate, who was perhaps the most outstanding of Suárez's students, teaches that the existence of contracts and of any synallagmatic relationships is something that experience itself reveals as necessary ${ }^{53}$ From this view, the Aristotelian-scholastic tradition teaches that the naturally political character of man is manifested in the practice of commutation. Now, as it will be shown below, Aristotle thinks interchanges could disappear owing to frauds,

44 Thomas Aquinas, Summa theologice, II-II q. 61 a. 3.

45 Diego Basalenque, Historia de la provincia de San Nicolás Tolentino de Michoacán de la orden de nuestro padre san Agustín (Ciudad de México: Jus, 1963), 92.

46 Alonso de la Veracruz, De dominio infidelium et iusto bello (Ciudad de México: UNAM, 2007), §279.

47 Alonso de la Veracruz, De dominio infidelium et iusto bello, \$279.

48 Pedro de Oñate, De contractibus in genere (Romæ: Ex Typographia Francisci Caballi, 1647), I.i §§3-

7.

49 Francisco García, Tratado utilísimo y muy general de todos los contratos (1583) (Pamplona: Eunsa, 2003), I.xxiii.

50 Juan de Zapata y Sandoval, De iustitia distributiva et acceptione personarum (Madrid: CSIC, 2004), I.iii $\$ 6$.

51 Zapata y Sandoval, De iustitia distributiva, I.iii §§13-14.

52 Zapata y Sandoval, De iustitia distributiva, I.iii §6.

53 García, Tratado utilísimo, Præfatio ad lectorem. 
to the contractual bad faith, to the unreasonable nullification of synallagmas, and to unjustified doubts of the parties on the validity of their agreements.

\section{RESTITUTIO AND SYNALLÁGMATA IN ARISTOTLE'S PHILOSOPHY}

As I have previously said, Aristotle seems not to circumscribe commutative justice to restitution. He elaborates his theory of the corrective just on the basis of the principle that justice is a virtue that establishes equalities. ${ }^{54}$ By extending this principle to the field of synallágmata ( $\left.\sigma v v \alpha \lambda \lambda \alpha \gamma_{\mu} \mu \tau \alpha\right)$, we infer that commutative justice is the virtue that establishes the equality of all contracts and transactions between private subjects.

Justice renders us just agents ${ }^{55}$ it impels us to do justice and to wish what is just, and moves us to use virtue for the benefit of others, ${ }^{56}$ which is a difficult task. ${ }^{57}$ The main challenge, therefore, is to become virtuous and not only to adjust one's own conduct to duty (to put it in Kantian terminology). In similar fashion, justice belongs to the beautiful things, ${ }^{58}$ it saves the equality in human dealings, ${ }^{59}$ and it restrains us from desiring the goods of others. ${ }^{60}$ Overcoming greed also belongs to justice. ${ }^{61}$ Moreover, this virtue commands us to "do good for the benefit of as many as possible." ${ }^{62}$ Its standard is nobleness. ${ }^{63}$ A virtue with these characteristics can hardly be restricted to compensation alone. These and other passages from the Aristotelian corpus show that corrective justice, like the other moral virtues, has a perfective (and not only remedial) function in the acts and character of persons.

As R. Polansky writes, Aristotle does not really speak of 'rectificatory justice', but rather of 'the just in commutations'. However, he refers to tò $\delta 10 \rho \theta \omega \tau \iota \kappa o ́ v$, often understood as 'the corrective' or 'the rectifying'. ${ }^{64}$ In Polansky's view, this translation seems to have misled scholars. Aristotle's

54 Aristotle, Ethica Nicomachea, E 3 §§1-3.

55 Aristotle, Ethica Nicomachea, A 8 §12; B 1 §4; B 1 §7; B 4 §1; E 1 §3; E 5 §17; Protrepticus (Madrid: Abada, 2006), frag. 40; Ethica Eudemia, B 7 §8.

56 Aristotle, Ethica Nicomachea, E 6 §6 (even E 1 § 16-18).

57 Aristotle, Ethica Nicomachea, E 1 \$18.

58 Aristotle, Artis rhetorica, A $9 \$ 23$.

59 Aristotle, Magna moralia, A 33 §§5-6; De iustitia (Librorum deperditorum fragmenta, Berolini, W. de Gruyter, 1987), frag. 3 .

60 Aristotle, Protrepticus, frag. 43a.

61 Aristotle, De republica Atheniensium (New Jersey: The Lawbook Exchange, 20043), VI §3.

62 Aristotle, De iustitia, frag. 3.

63 Aristotle, Magna moralia, B 9 \$2.

64 Ronald Polansky, "Giving Justice Its Due", in The Cambridge Companion to Aristotle's Nicomachean Ethics, ed. Ronald Polansky (Cambridge/New York: Cambridge University Press, 2014), 161. 
concern is with the just in commutations and not solely with correcting them when they go wrong, as broadly assumed. ${ }^{65}$ Thus, although it has been widely understood as a rectifying virtue, for "it typically comes into play after an injustice has arisen [...] it also gets things straight in advance, as in drawing up a contract." $" 66$

Many reasons render improbable the reduction of the Aristotelian virtue of the commutative justice to restitution. Just to mention some: the Aristotelian doctrine of the private contract ( $\sigma \nu v \theta \eta \dot{\kappa} \kappa \eta)$, which is a law for the parties; ${ }^{67}$ the broad sense that Aristotle assigns to the mandate to give each person their due ${ }^{68}$ his censure of unfair enrichment (hand in hand with the assertion that retaining what belongs to someone else is unjust ${ }^{69}$ ); to say nothing of his defense of the obligatory character of the given word. On the other hand, the Stagirite takes for granted the validity of contracts. ${ }^{70} \mathrm{He}$ affirms that if we begin to invalidate our agreements with others, "there will be an end to social relationships.",71

The precept of giving each one their due is related to the idea that the upright man does not do what could be harmful or inconvenient to others. In this context, it is clear that giving each one their due not only imposes a reparation, i.e. the equalization of the situation of the parties after the damage or noncompliance has occurred. It also imposes the good faith and the equivalency of what is handed over and what is received. G. Prisco, wanting to explain the Aristotelian thesis of contractual justice, writes that " $<$ according to the order of the corrective just $>$ the will of the contracting parties is to receive a thing equivalent to that which each one gives." 72 The parties wish that the agreement be equal from the very start (so, according to the division of justice 'invented by Aristotle', the just contract will not give more profits to one nor heavier burdens to the other than those due $^{73}$ ).

The contracts - which are balances of interests in the Aristotelian typology-, will be fair only if the parties equally participate in profits and losses. The idea

65 Polansky, "Giving Justice", 151-179.

66 Joe Sachs, Aristotle: Nicomachean Ethics (Indianapolis: Focus/Hackett, 2011), 83n.

67 Aristotle, Artis rhetorica, A $15 \$ 21$.

68 Aristotle, Ethica Nicomachea, E $4 \S \S 13-14 ;$ E $5 \S \S 17-18 ; \Theta 7 \S 3 ; \Theta 11 \S \S 3-4 ;$ I 2 §; De iustitia, frag. 3; Magna moralia, B $3 \S 3$; Artis rhetorica, A 9 §7; B 9 \$10-11.

69 Aristotle, De sophisticis elenchis (Cambridge/Harvard: Harvard University Press, LCL 400, 1955), XXV.

70 Aristotle, Artis rhetorica, A $15 \$ \$ 21-22$.

71 Aristotle, Artis rhetorica, A $15 \S 22$.

72 Giuseppe Prisco, Principii di filosofia del diritto sulle basi dell'etica (Napoli: Manfredi, 1872), 270.

73 Joaquín Escriche, Diccionario razonado de legislación y jurisprudencia (París: Librería de Rosa, Bouret y Cia., 1852), 1132. 
of 'profit' is one of the central concepts of the Aristotelian doctrine of contracts. Among other things, this concept allows Aristotle to explain the injustice of commutative relationships, the vice of pleonexia, the unfair enrichment, the binding force (and presumption of validity) of legitimately concluded contracts, the idea of inequity, and so on. While the notion of 'gain' proceeds from voluntary transactions ( $\tau \alpha \dot{\varepsilon} \dot{\varepsilon} \kappa o v ́ \sigma 1 \alpha \sigma v v \alpha \lambda \lambda \dot{\alpha} \gamma \mu \alpha \tau \alpha$ ), by analogy it can be used to describe the type of imbalance that harm/injury causes within involuntary

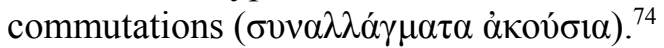

Aristotle assumes that all harm involves an illicit gain. ${ }^{75} \mathrm{He}$ writes that "we speak of profit for the attacker who wounded his victim [...] even if that is not the proper word for some cases." 76 The reason is simple: just like the unjust man becomes richer because of injustice, so does the offender become richer because of the offense. ${ }^{77}$ Under the logic of loss and profit, Aristotle argues that to have more implies inequity, so that if justice is a sort of equality, injustice is a sort of inequality. ${ }^{78}$ For all these reasons, he notes that

[...] when men apportion to themselves the larger share of good things and the less share of evil things, this is unequal, and we say that injustice is done and suffered $[\ldots]$ therefore, the virtue of justice is a mean betwixt excess and defect, much and little. By doing injustice the unjust man receives more; through suffering injustice, the wronged man receives less. The mean state betwixt this more and less is justice; and such a mean is equality. ${ }^{79}$

In breached contracts, one of the parties has become richer at the expense of the impoverishment of the other. ${ }^{80}$ This produces a certain 'displacement' of goods from one hand to another. ${ }^{81}$ Then, in order to re-establish the commutative order that existed before the unjustified enrichment, a judge will have to intervene, at least as stated in the Ethica Nicomachea -in the Ethica

74 Aristotle, Ethica Nicomachea, E 4 §§4-6; E 4 §13.

75 Aristotle, Ethica Nicomachea, E 2 § ; E 2 §4-5.

76 Aristotle, Ethica Nicomachea, E 4 §5.

77 Aristotle, Ethica Nicomachea, E 2 §§2-6; E 6 §4; Magna moralia, A 33 §§4-7.

78 Aristotle, Ethica Nicomachea, E $3 \S \S 1-3 ;$ E 4 §3; Magna moralia, A 33 §4.

79 Aristotle, Magna moralia, A 33 §\$-6.

80 Aristotle, Ethica Nicomachea, E 2 §13; E 4 §§4-13; E 5 §18.

81 Michel Villey, Le droit et les droits de l'homme (Paris: PUF, 2016), 37-54; Constantin Despotopoulos, Aristote sur la famille et la justice (Bruxelles: Ousia, 1983), 119; Weinrib, The Idea of Private Law, 56; Jorge López Santa María \& Fabián Elorriaga, Los contratos. Parte general (Santiago: Legal/ Thomson, 2010), 16. 
Eudemia, Aristotle seems to support a different thesis: it is reasonable for the parties themselves to resolve the impasse that confronts them. ${ }^{82}$

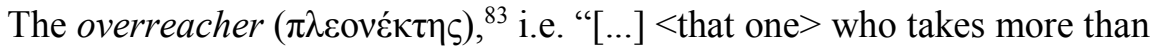
his due, ${ }{ }^{84}$ must surrender to the offended party what is theirs. For this goal, the judge will order the restitution. Now, forced restitution is not, properly speaking, an act of virtue. As it is said in the Artis rhetoricce, men act voluntarily when they know what they do and do not act under compulsion. ${ }^{85}$ Therefore, if the act of restitution is not voluntary, then it will not be an act of justice either. Given that, how could corrective justice be defined by an act that does not perfect the person or make him genuinely good?

Aristotle adds that it is not properly a morally good action to fulfill an agreement or to deliver what is due because of fear or of the imposition of the tribunal. Even though such acts may be called materialiter just, they will not be such formaliter. Here, at best, one can speak of an accidental justice ${ }^{86}$ Moreover, the judge intervenes to remedy the imbalance between the profits and losses of the parties, but, what if no one wins or loses? What if the buyer has paid what is due to the seller and he has delivered the agreed good to the buyer? If no one obtains benefits or suffers losses, i.e. if the rights of the parties, or the parties themselves, do not suffer damages of any kind, what role will the justice have, if any at all? It seems clear to me that the equivalence of the reciprocal obligations and the execution in good faith of the contract by those to whom the synallagma obliges is the task of commutative virtue.

The corrective justice has a positive and a negative aspect. The former refers to the mandate to seek the good and to contribute to the further development of everyone else. The latter, on the other side, relates to the mandate not to harm, the contravention of which gives rise to the obligation to restitute. Aristotle's thesis echoes the ancient definition of justice as the virtue that orders declinare a malo et facere bonum. That being so, the virtuous life the one that the righteous lives- is only achieved by rejecting vice and doing

82 Aristotle, Ethica Nicomachea, E 4 $\S 7-8$; Ethica Eudemia, H 10 §19. Although Aristotle in Ethica Nicomachea (I 1) attests to laws that prohibit legal actions in voluntary transactions, he affirms nothing there about the inconvenience filling a lawsuit against who breaches a contract; he does explicitly allow that possibility in Ethica Eudemia.

83 Aristotle, Ethica Nicomachea, E 1 §§8-9; E 2 §2.

84 This is how Rackham translates pleonéktēs. Broadie says instead "the grasping, i.e. unequal-minded". See, respectively, The Nicomachean Ethics (Cambridge/London: Harvard University Press, LCL 73, 1934, trans. Harris Rackham), 257; and Aristotle: Nicomachean Ethics (Oxford: Oxford University Press, 2002, ed. Sarah Broadie \& Christopher Rowe), 159.

85 Aristotle, Artis rhetorica, A $10 \S 3$.

86 Aristotle, Ethica Nicomachea, E 8 §4. 
just things. ${ }^{87}$ As a consequence, Aristotle -or the authentic author of Economica- states that life according to justice consists in moving away from the dishonorable and in doing that which is good and honorable. ${ }^{88}$

Aristotle's presumably 'rectifying' explanation reflects more the legal system in force in Classical Greece rather than reasons of a philosophical nature. In ancient Greek law, the notions of responsibility, equality, obligationes contractce-quoquo modo contractce, in Gaius' words-, etc., seem to have a reparative origin. ${ }^{89}$ As specialists point out, ancient Greek law is more concerned with handling guilt than with the contractual freedom or autonomy of will. Thus, for the Greek-Classical legal system, the main effect of legal acts and facts is responsibility; possibly, the normative system of Classical Greece was almost solely composed of prohibitive rules; this would explain the Aristotelian idea that the just man is the one who does not break the law. ${ }^{90}$

In this perspective, the obligation deriving from the involuntary synallagma constitutes the first analogue of the set of duties that take place in contracts and commutative dealings. From my point of view, this could explain Aristotle's special concern for the restorative aspect of corrective justice, a concern revealed in the emphasis that the author puts in the natural iniquity of some commutations, such as adultery, theft and murder, actions which, in another place, he describes as acts whose names "automatically include baseness" (and which here are treated as commutative injustices). ${ }^{91}$ There is no doubt that, in the presence of damages, this justice will fundamentally have a restitutive function, which does not mean that the 'corrective' character of this virtue is exhausted, for Aristotle, with the compensation. As I see it, this justice is called 'corrective' not really because it 'corrects' but because it makes the synallagmatic nexus 'straight', 'correct', even 'healthy'. For this reason,

87 Aristotle, Ethica Nicomachea, B 1 \$4.

88 Pseudo-Aristotle, Economica (Cambridge/London: Harvard University Press, LCL 287, 1935), $\Gamma 4$.

89 Hans Julius Wolff, "The Origin of Judicial Litigation among the Greeks", Traditio 4 (1946): 31-87; "La structure de l'obligation contractuelle en droit grec", Revue historique de droit français et étranger 4 (1966): 569-583; "Diritto greco, diritto tolemaico", Dike 16 (2013): 97-122; "Greek Legal History: Its Functions and Potentialities", Washington University Law Review 2 (1975): 395-408; Despotopoulos, "La notion de synallagma chez Aristote", 115-127.

90 Aristotle, Artis rhetorica, A 10 §3.

91 "A second species $<$ of particular justice $>$ concerns rectification in transactions. This second species has two parts, since one sort of transaction is voluntary, and one involuntary. Voluntary transactions (for instance, selling, buying, lending, pledging, renting, depositing, hiring out) are so called because their principle is voluntary. Among involuntary transactions some are secret (for instance, theft, adultery, poisoning, pimping, slavedeception, murder by treachery, false witness), whereas others involve force (for instance, imprisonment, murder, plunder, mutilation, slander, insult)". Aristotle, Ethica Nicomachea, E 2 §§12-13. 
medieval authors understood this virtue as regulativa sive correctiva, in commutatibus directiva.

The Aristotelian exposition of corrective justice is based on the relationship between diorthotic justice and synallagma: diorthotic justice is the habit that regulates synallágmata. This is what Aristotle states in Ethica E 4: "Tò $\delta \dot{\varepsilon}$

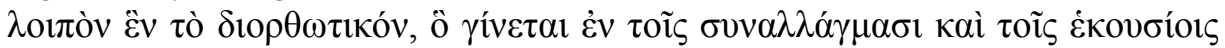

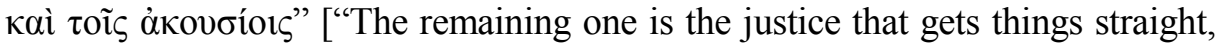
which comes about in transactions of both the willing and the unwilling sort"92]. Before addressing the question of the nature of synallagmas, it is worth clarifying that, in strict terms, it is more appropriate to speak of 'corrective

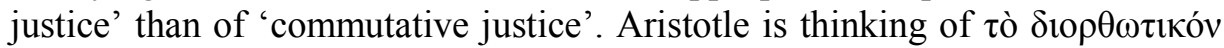
Síkalov, a term that Robert Grosseteste, in the first decades of the 13th century, translates as iustum directivum. ${ }^{93}$ Grosseteste thus implies that the corrective just comprehends both the fulfillment/breach of covenants and contracts, and the duty to compensate that falls on the offender because of the harm he has caused to others.

A medieval interpretation of Aristotle that does not restrict corrective justice to restitution is offered by the Arabic version of the Ethica Nicomachea. The Arabic translation of Ethica E 4 introduces the concepts of 'health', 'integrity', 'perfection' (the term used is 'șahịh') into its description of the corrective just. Arguably, this conceptual background -as well as the cultural preconceptions resulting from the Koranic view of justice- obliges the translator to present corrective justice as that which directs/ordinates social relations and not only commercial exchanges and acts of restitution, which is arguably a correct interpretation of Aristotle's mind. ${ }^{94}$

The distinction between voluntary and involuntary synallagmas follows the logic of efficient causality. In other words, the distinction between voluntary and involuntary commutations is that, in the former, the origin of the

92 I am quoting here the edition of Sachs: Aristotle: Nicomachean Ethics (Indianapolis: Focus/Hackett, 2011, trans. Joe Sachs).

93 Aristotle, Ethica Nicomachea. Translatio Roberti Grosseteste Lincolniensis sive Liber Ethicorum: Recensio pura, XXVI 1-3/3, ed. René Antoine Gauthier (Leiden/Bruxelles: Brill/Desclée, 1972), E4[7]/233-234. Von Kirchmann's proposal is even better, because, when explaining the modes of particular justice, he speaks of the constitutive rather than the commutative just. Julius von Kirchmann, Erläuterungen zur Nikomachischen Ethik des Aristoteles (Leipzig: L. Heimann's Verlag, 1876), 92.

94 The Arabic translation of the Ethica Nicomachea E 4 reads: "The remaining one is in the class of the corrective in social relations and in things voluntary and involuntary". However, a little further down the Arabic translator does give synállagma the meaning of private business/contract: " ... the justice which is in transactions, it is something equal, and injustice is unequal, but not in accordance with the previous proportion, rather in accordance with numerical proportion": The Arabic Version of the Nicomachean Ethics, ed. Anna A. Akasoy, Alexander Fidora \& Douglas M. Dunlop (Leiden/Boston: Brill, 2005). 
synallagmatic relationship is voluntary (the man who is subsequently injured has freely entered into that relationship), ${ }^{95}$ unlike the equivocally called 'involuntary contracts', which is an 'elegant expression' but 'inappropriate', as Vico notes, for it does not help to understand the nature of the harmful acts that are subject to the regulation of the commutative justice. ${ }^{96}$

The double mode of the synallagmas of Ethica Nicomachea corresponds to the double cause of obligations mentioned in Artis rhetorica. According to the structure of text, the analysis of the different nature of common and particular law begins with the assertion that all transactions are reduced to the categories of 'delict' ( $\alpha \delta i ́ \kappa \eta \mu \alpha)$ and 'right action' $(\delta \kappa \alpha \alpha i \omega \mu \alpha) .{ }^{97}$ The same distinction contract/delict is developed, mutatis mutandis, by the Roman jurists -Labeo even remarks that the Latin notion of voluntary contract, ultro citroque obligatio, coincides with what the Greeks call synállagma ("quod Græci $\sigma v v o ́ \lambda \lambda \alpha \gamma \mu \alpha$ vocant"). ${ }^{98}$

Gaius, certainly under the influence of Greek Law and of Aristotle (or the Peripatetics), ${ }^{99}$ holds that the two great and only sources of obligations are the delict and the contract. ${ }^{100}$ The Corpus iuris civilis, in the same line, does not limit the formula contrahere to convention. As a result, according to the Justinian compilation, delicts and obligations derived from insult, injury, damage, prejudice, etc., are also 'contracted'. Thereupon, the notion of synállagma/contractus, generally used in commercial transactions, often designates among ancient thinkers "any type of legal obligation regardless of its creation, be it an offense or a contract."101 Synállagma is, hence, 'the contracted', that idea that is expressed with the passive participle of the verb contrahere and not the contract-consensus.

95 Ross, Aristotle, 220.

96 Giambattista Vico, De universi iuris principio et fine uno (Amsterdam/Atlanta: Rodoni, 2000),

XLIII.vi.

97 Aristotle, Artis rhetorica, A $13 \S 1$.

98 Justinian, Digesta Iustiniani Augusti (Berolini: Weidmannos, 1870), 50.16.19.

99 For a similar position, vid. Fritz Schulz, Classical Roman Law (Oxford: Clarendon Press, 1961), $465-$ 468; Reinhard Zimmermann, The Law of Obligations: Roman Foundations of the Civilian Tradition (Oxford/New York: Oxford University Press, 1996), 10-11; T. Honoré, Gaius (Oxford, Clarendon Press, 1962), 97-ss; Alfredo di Pietro, Derecho privado romano (Buenos Aires: Depalma, 19992), 187. Bastit, in view of the singular closeness of Gaius' thesis to Aristotle's proposal, invites the reader to recognize that the jurist, although we do not know with certainty the level of knowledge he had of the Greek sources, is the one who is closest to the realistic legal vision proposed by the Aristotelian philosophy. Vid. Michel Bastit, "La diversité dans les Institutes de Gaius", Archives de philosophie du droit 23 (1978): 333-343.

100 Gaius, Institutiones (Oxford, Clarendon Press, 1904), III $§ 88$.

101 Gottfried Schiemann, "Synallagma", in Brill's New Pauly. Encyclopaedia of the Ancient World: Antiquity, eds. H. Cancik \& H. Schneider, retrieved from http://dx.doi.org/10.1163/1574-9347_bnp_e1127030. 
G. Bien speaks of 'relationship' in order to avoid difficulties of defining synállagma as 'exchange', 'transaction' or 'intercourse', ${ }^{102}$ terms that, as F. Chénedé observes, do not accurately express the Aristotelian notion of synállagma. ${ }^{103}$ Strictly, synállagma is nothing more than any juridically cognizable relation that exists between two private individuals by the free act of one or both. ${ }^{104}$ This reason has led some contemporary Aristotelians to speak of 'interactions' ${ }^{105}$ Because of the above considerations, R. Martini asserts that the most appropriate thing is to give the Aristotelian term synallágmata the meaning of 'intersubjective relations', ${ }^{106}$ and F. Schulz stresses that Aristotle simply uses the term synallágmata in the sense of 'acts which entail an obligation'. ${ }^{107}$

Michael of Ephesus advances a proposal to overcome the conceptual ambiguity regarding the diverse nature of synallagmatic obligations, ex contractu, in some cases, and ex delicto, in others. According to Ephesius, "the Ancients use the term synallágmata not only to speak about legal $<$ commutations $>$ that have their origin in mutual agreements, but also to $<$ refer to $>$ acts prohibited by law." 108 However, the effort of this Aristotelian seems to have been lost in time. By the end of the Middle Ages, almost no jurist was interested in the study of the meaning of the term synállagma, and, according to the reports of Francisco de Araújo, at the dawn of Modernity, corrective justice is almost universally conceived as the virtue governing agreements and conventions, to the point of defining it as the justice that determines the debit of contracts and bilateral businesses. ${ }^{109}$

102 Günther Bien, “Aristotle on Justice (Book V)”, in Aristotle's Nicomachean Ethics, ed. Otfried Höffe (Leiden/Boston: Brill, 2010), 109-131.

103 François Chénedé, Les commutations en droit privé (Paris: Economica, 2008), 2.

104 Aristotle, The Nicomachean Ethics, eds. H.H. Joachim \& D.A. Rees (Oxford: Clarendon Press, 1956), 136.

105 Aristotle, Nicomachean Ethics, eds. S. Broadie \& Ch. Rowe(Oxford: Oxford University Press, 2011), 162-163, 339; Ethics, eds. J. Barnes \& A. Kenny (Princeton: Princeton University Press, 2014), 98.

106 Remo Martini, Diritti greci (Torino: Zanichelli, 2005), 69-70.

107 Schulz, Classical Roman Law, 468.

108 Michael of Ephesus, In librum quintum Ethicorum (Berolini: Georgii Reimeri, 1901), f. 65v. In Englard's opinion, Ephesius' commentary on Aristotle's moral theses reveal his inclination "for the explanation of the different (mathematical) proportions". Izhak Englard, Corrective and Distributive Justice (Oxford/New York: Oxford University Press, 2009), 11n.

109 Francisco de Araújo, Las leyes (1638) (Pamplona: Eunsa, 2010), 406. 


\section{SUÁREZ, CORRECTIVE JUSTICE AND THE OBLIGATION TO GIVE EACH ONE HIS RIGHT}

The historiography of the reception of the synallágmata in the ius civile tradition reveals the absolute unanimity of the consensualist reading of Aristotle towards the end of the Middle Ages. Simultaneously, the thinkers of the time frequently noticed that synállagma equates to a commercium. ${ }^{110}$ This is an indisputably trade-orientated comprehension of the Greco-Roman contractual doctrine, which reaches its maximum development in Grotius. ${ }^{111}$ Unsurprisingly, Pedro de Osma, the famous Salamanca Aristotelian of the 15th century, adheres to this interpretation and defines synállagma in terms of agreement/ convention. ${ }^{112}$

Although it is not the case of Suárez, whose commentary I will discuss next, it is worth noting that other interpreters of Aristotle are more accurate when commenting the legal ideas in the Ethica Nicomachea. Thereby, Camerarius, a German humanist, managed to overcome the conceptual deadlock that derived from the reductionist sense given over time to the synallágmata, which forced modern interpreters to speak of involuntary contracts. With great philosophical and philological precision, Camerarius describes corrective justice as that which deals with 'things that are contracted' -and not with contracts themselves. This justice, he adds, dictates the reciprocal obligations of the parties, making 'correct' (in the sense noted above) the equality or arithmetical measure of the duty which is object of this virtue. ${ }^{113}$

The Suárezian understanding of corrective justice cannot be understood outside of this renewed interpretation of the synallágmata. Suárez remains faithful to the exegetical tradition initiated by Aquinas. Hence, he describes the corrective just as the rule of contracts, just like Aquinas interpreted in a

110 Most of the humanists interpret this way the Greek synállagma, which is a concept they deduce from the doctrine of innominate contracts. Medieval authors refer with this term to human businesses that imply a dare or a facere, of the kind do ut des, do ut facias, facio ut des, and facio ut facias. Vid. Alejandro Guzmán Brito, "Para la historia de la formación de la teoría general del acto o negocio jurídico y del contrato. IV: Los orígenes históricos de la noción general de acto o negocio jurídico", Revista de Estudios Histórico-Jurídicos 26 (2004): 187-254.

111 In this regard, Grotius states that "all acts... advantageous to others, except those which are of mere generosity, are called contracts". Hugo de Groot, De iure belli ac pacis (Indianapolis: Liberty Fund, 2005), II.xii.7.

112 Pedro de Osma, Commentaria in Ethicorum libros Aristotelis (Salamanca: Universidad Pontificia de Salamanca, 1996), ff. 74-93. Osma goes so far to say that the principal subject matter of corrective justice is the equality of 'commercia'.

113 Joachim Camerarius, Ethicorum Aristotelis Nicomachiorum explicatio (Francofurti, 1628), V 4. 
commutative way the fifth book of the Ethica Nicomachea. ${ }^{114}$ Thus, Suárez states that corrective justice "is the one concerned with observing the right of the other $[\ldots]$ in contracts and commutations, which are the acts that give the name to this justice."115

I include Suárez in the catalog of commentators on Aristotle's works because, as I said before, he has left a commentary on each of the books of the Ethica, which is preserved, along with some notes on the Magna moralia, in manuscript lat. 6775 of the Bibliothèque Nationale de France. This codex which remains unpublished-groups together a set of lectures that Suárez, following the disputation method, presumably delivered at the Collegio Romano during the few years he stayed there.

Although the codex is not as insightful as De legibus ac Deo legislatore or Defensio fidei catholica, it is nevertheless a very interesting work, because it accounts for Suárez's effort to highlight the strictly Aristotelian elements of the natural law tradition, for example, the principle that holds that it is better to act justly than to know what virtue is ${ }^{116}$ (in Aristotle's own words, "We desire to know virtue; but at the same time we desire to be virtuous ourselves"117). In Suárez's manuscript, corrective justice is presented as the order in commutations. Every commutation, Suárez says, entails a handing over and a retribution: whoever hands over something receives something else in return. Now, what is handed over and what is received must share a common measure. If corrective justice did not order the equivalence of benefits, there would be no contracts or commutative relations of any kind, since no one enters into a contract at the expense of his person or his patrimony. On the subject of involuntary dealings, the codex merely affirms that corrective justice is also the norm for this kind of synallagma, since this virtue directs each and every one of the legal relations occurring between private persons. ${ }^{118}$ The vast majority of

114 Commentarii in Ethica Aristotelis, ff. $84 \mathrm{r}-87 \mathrm{v}, 100 \mathrm{v}-105 \mathrm{r}$. It is not my intention to assimilate Suárez' thought to that of Aquinas, or, correspondingly, to accentuate the 'Thomism' in Suárez's system. The aforementioned similarity between the Thomistic and Suárezian commentaries to Aristotle's legal theory is a matter of fact. It could be accounted for by various reasons, like the historical context in which Suárez imparted his lessons, the Ignatian directive of adhering to Thomas Aquinas in Theology, Suárez' admiration for the work and personality of Aquinas, among many other.

115 Qucestiones de iustitia et iure, d. IV, q. 3, f. 39v.

116 Hence, we read in Aristotle's Ethica that "the purpose of our examination is not to know what virtue is, but to become good".

117 Aristotle, Magna moralia, A $1 \S 4$. Aristotle holds that "... it may fairly be maintained that a knowledge of virtue is useless, unless one also understands how and from what elements it can be produced. Not only must we consider how we shall know its nature, but from what constituents we may form it. $<$ Therefore, $>$ we desire to know virtue; but at the same time we desire to be virtuous ourselves".

118 Commentarii in Ethica Aristotelis, ff. 84r-87v, 100v-105r. 
Aristotle's commentators and of the late scholastics who wrote treatises on $D e$ legibus and De iure et iustitia, say scarcely anything else. They only add, like Suárez, that most human affairs that give rise to co-respective obligations are born from the will. ${ }^{119}$

Insofar as it is a general virtue, justice is the habit that commands respect for the rights of others and for the practice of equity. ${ }^{120}$ The act of giving each one their due is the 'task of justice', ${ }^{121}$ which, as in other moral virtues, is defined more by the internal will than by external conduct. ${ }^{122}$ For this reason, Suárez argues that external acts are not properly called good; their honesty rather depends on the internal acts. ${ }^{123}$ He sums up saying that " $<$ external acts $>$ can sometimes be called good and sometimes bad, <but only $>$ because of the internal acts from which they originate." 124 Additionally, Suárez explains that acts of justice are difficult. ${ }^{125}$ Yet, when we achieve virtue, "we act justly with promptness, ease and constancy." 126

Each virtue is defined through its object. Thus, if corrective justice is a true virtue, it must have an object of its own. Moreover, if it is a true kind of justice, its object must be different from that of legal justice and distributive justice. Such an object, according to Suárez, is the dominion that each person has over their things (something like one's own dominion over one's own things). ${ }^{127}$ Consequently, Suárez postulates that:

[...] each person holds their own dominion over their own things. A particular community or the whole society has also some ownership or dominion over certain things, in the way that the private person $<$ has dominion over what is theirs $>$. Even the king, <who is a $>$ public person, has a dominion [...] over the things of which he is a special lord. This is the right that commutative justice [...] considers and respects, whatever person or community he belongs to. Well, for a right to be <in the hands $>$ of the whole community, of a public person or of a private individual is something rather material and accidental, because $<$ that right, whatever it is, $>$ always has the same condition. ${ }^{128}$

119 De legibus ac Deo legislatore, 1. I, c. 14, n. 3.

120 Qucestiones de iustitia et iure, d. III, q. 1, f. 30v; d. III, q. 2, f. 32r.

121 Qucestiones de iustitia et iure, d. III, q. 1, f. 31v.

122 Qucestiones de iustitia et iure, d. III, q. 1, f. 31r.

123 Qucestiones de iustitia et iure, d. III, q. 2, f. 32r.

124 Qucestiones de iustitia et iure, d. III, q. 2, f. 32r.

125 Qucestiones de iustitia et iure, d. IV, q. 1, f. 33v.

126 Qucestiones de iustitia et iure, d. IV, q. 1, f. 33v.

127 De iustitia Dei, s. IV, n. 6.

128 De iustitia Dei, s. IV, n. 6. "For the rest, the republic, or the king, insofar as it is the person... to whom the people have transferred their rights, has (I mean) a certain 'high dominion', that is, $<$ a right $>$ of superior order 
In a complementary way, it is read in De iustitia et iure:

[...] if a citizen usurps the things common to the republic, that is, if he steals them, he commits a sin against commutative justice [...] therefore, he is obliged to restitute $<$ what he stole $>$, because restitution, according to the doctrine of Aquinas, is the proper act of commutative justice. $<$ Likewise, $>[\ldots]$ the republic owns its goods in the same way as citizens $<$ own $>$ theirs. Thus, justice itself obliges us to respect this right in the same way $<$ that it obliges us to respect the dominion of the particular person $>.{ }^{129}$

Commutative equality is arithmetic, i.e. it is an equality from thing to thing. This is how Suárez expresses it in several passages of De legibus ac Deo legislatore. ${ }^{130}$ That being so, the nature of the parties is of corrective importance only when the situation of the transgressor/delinquent/offender increases the magnitude of the injury and only with a view to reparation.

The ideal of justice, to give to each one their due, is fully realized in corrective justice. Suárez points out that we are discussing here the justice of civil subject-matters, which does not take into account the singularities of the parties, but only the parity of the obligations. Hence, Suárez teaches that this special virtue is that which attributes to each one their own right. ${ }^{131}$

Suárez's trade-bias of the corrective justice can be observed, for example, in De iustitia Dei. Here the author affirms that "the proper and adequate subjectmatter of commutative justice -as the name itself declares it - is the mutual handing over and reception < of something $>$, which is a certain commutation." 132 Now, "the formal object of this justice consists in the equity of what is given and what is received." 133 When the relation of obligations is not equitable, that is to say, when profits and losses are not proportionate, commutative justice imposes the duty to turn that inequality into equity. ${ }^{134}$ In Suárez's own words,

over the goods of the citizens... which $<$ evidently $>$ does not exclude private dominion $<$ of private individuals $>$. In spite of what has been said, $<$ that is to say, in spite of the fact that the individuals still have true dominion over their things $>$, <the so-called 'high dominion'> confers $<$ on the authority the right $>$ to use those goods for the common benefit of the republic when the need commanded it. This right obliges the members of the republic not to subtract their goods and not to deny them to the authority when necessary... Now, the republic has this kind of dominion or right not only over external things <private>, but also over the same people and their actions, and even over their lives -although not in the sense that it can take their lives at will, but insofar as it can expose $<$ private individuals $>$, with all justice, to any danger... if necessary".

129 Qucestiones de iustitia et iure, d. IV, q. 2, f. 37v.

130 For instance, in De legibus ac Deo legislatore, 1. V, c. 12, n. 10; 1. V, c. 15, n. 4; 1. V, c. 16, n. 1.

131 De iustitia Dei, s. II, n. 3.

132 De iustitia Dei, s. II, n. 6.

133 De iustitia Dei, s. II, n. 6.

134 De iustitia Dei, s. II, n. 6. 
This is how Aristotle explains the object and reason of justice in the Ethica Nicomachea, $<$ a line of arguments $>$ which leads him to state that commutative justice deals only with three genres of goods, namely money, honor and health -only in these is equity constituted or respected $-[\ldots]<$ Aristotle $>$ adds $[\ldots]$ that $<$ the obligation arising from commutative justice $>$ exists in spontaneous exchanges $<$ that is, in those whose principle is the will of the parties $>$ and in the injustice perpetrated involuntarily among men. ${ }^{135}$

The principle governing the fairness among the parties' considerations is called the principle of equivalence. The role of this principle in Suárez's theory of contracts shows that he does not grasp corrective justice as merely reparative. He remarks that commutative justice institutes the legal relations among private persons. ${ }^{136}$ Therefore, the proportion that defines commutative relations must already exist at the moment of the celebration of the act or contract. Suárez does not say so, but it is clear that the parties of the agreement expect that the ratio of profit and loss that binds them is adequate from its origin.

\section{THE SCHOLASTIC AND SUÁREZIAN THEORY OF RESTITUTION}

As it has been said above, 'equality', 'injury', 'unjustified enrichment', 'benefits equivalence', etc., are central concepts in the Aristotelian and Scholastic theory of corrective justice. The same is true of Aristotle's notion of synallagma. Undoubtedly, compensation for illicit profits is an important factor in the practical philosophy of classic thinkers, but his legal theory is more interested in the execution of contracts in good faith, in the equitableness of the parties, in the respect for others' rights, and in the fulfillment of the given word and of the freely contracted obligations. Since this constructive/positive aspect of corrective justice has been dealt with extensively in the previous sections, I will devote this last part to the strict problem of restitution.

Similar to other scholastics, Francisco Suárez constructs his ethics of restitution starting from the concept of unjust enrichment; like the Stagirite, Suárez gives to the idea of illicit gains the broadest possible sense, only restricting it to the infliction of some wrong-doing of a commutative nature.

135 De iustitia Dei, s. II, n. 6. Later on, Suárez writes: "It follows from what has been said that it is true that commutative justice deals only with three goods, namely, money, honor, and health... for only in these goods does it seem that one man can harm another or give him something back. Now, fame must be thought of as $<\mathrm{a}$ form of $>$ honor and all the intrinsic goods of the body must be included in health... Likewise, under money must be understood all the goods of the same order and which are monetarily appreciable" (ibid., n. 22).

136 De iustitia Dei, s. II, n. 7. 
Accordingly, he maintains that whoever injures someone without a proportionate reason, profits in some way from it; hence, they must restitute. ${ }^{137}$

Bartolomé Carranza, the famous Toledo archbishop who was accused of heresy by the Holy Office, sums up the Aristotelian Scholastic doctrine of restitution in a very simple principle: if I have not become richer, I am not obliged to compensate. ${ }^{138}$ Carranza adds that any injury to others' rights requires compensation, regardless of whether the offender has obtained an economic benefit from it. ${ }^{139}$ Suárez, whose conception of restitution depends on a kind of general duty of respecting the property of others -the Eximius thinks that respect for others' dominion is the main subject matter of the corrective justcompletes Carranza's thesis by saying that, on account of commutative justice, no one is obliged to renounce what is theirs unless the common good requires it. ${ }^{140}$ Save for this last motivation, any undue transfer of goods or values from one person to another is unfair, so that, whenever one takes what is alien without a just cause, it must be returned. ${ }^{141}$ In this regard, Suárez explains that:

[...] the same thing < said about voluntary dealings> can be said [...] of debts that originate between men by involuntary actions or passions and by offending actions. The reason is that $[\ldots]$ when someone hurts another or damages their honor or fame, etc., it affects their domain [...] thereby damaging $<$ also $>$ the thing of which $<$ the other $>$ had in domain or possession. Now, the same virtue of justice provides that $<$ the offender $>$ is obliged either to reinstate the right or the thing when possible or to return something equivalent if the due estimation proceeds..$^{142}$

In Suárez's terms, to restitute is tantamount to paying what is due. ${ }^{143}$ As it is well known, the legal notion of payment is not limited to the delivery of a sum of money to a seller or to the opposite party of a commercial transaction. Payment is one of the many modes of extinguishing an obligation. This being so, the person who restitutes, pays, because, when making the payment, the

137 Qucestiones de iustitia et iure, d. IV, q. 8, f. 51v; Commentarii in Ethica Aristotelis, ff. 100v-105r. Strictly speaking, this is a common thesis in Scholasticism. It even was defended by some medieval authors such as Albertus Magnus and Thomas Aquinas. They point out that 'whoever suffers something bad has less of what they want'. As a result, by harming someone, the robber or the murderer has more of what is esteemed good, since "they have done their own will and so seem as it were to have gained". That species of disequilibrium, Albertus says, "is correctly named 'loss' and 'profit". Albertus Magnus, In X Ethicorum (Paris: Vivès, 1891), V.ii.6; Thomas Aquinas, Sententia libri Ethicorum, n. 952.

138 Bartolomé Carranza, De iustitia (Pamplona: Eunsa, 2003), q. 62 a. 6.

139 Bartolomé Carranza, Catechismo christiano (Madrid: BAC, 1972), II/f. 261v.

140 De iustitia Dei, s. II, nn. 3 and 6.

141 De iustitia Dei, s. II, nn. 2-23.

142 De iustitia Dei, s. II, n. 3.

143 Defensio fidei, 1. III, c. 23, n. 17. 
debtor fulfills the duty that kept him synallagmatically bound to the creditor. Even if they come from classical Roman Law, the concepts of 'payment', 'commutative duties', 'debit' and 'extinction of obligations' were significantly enriched in the Spanish Scholasticism, especially thanks to the work of Francisco de Vitoria, Domingo de Soto, Luis de Molina and Suárez himself. In view of their thorough studies, the late scholastics are deemed as an antecedent of the French jurists' doctrine on civil obligations, ideas which are embodied, to this day, in the Napoleonic Civil Code.

As regards the Law of Restitution, modern Civil Law owes much to the scholastic theologians. ${ }^{144}$ As Th. Duve writes, before Domingo de Soto, the tradition of ius civile "had never [...] developed a general theory of restitution." 145 Similarly, J. Schumpeter underlines the lack of originality of Grotius, Pufendorf and other modern jurists in comparison to the richness of Second Scholasticism's ethics and economic theory. ${ }^{146}$ Without downplaying the role of the Spanish Scholastics in the History of Law, I think Schumpeter's judgment unduly disregards the efforts of the authors of the Modern School of Natural Law and the Codification Fathers. However, it must be said that the late scholastics dealt with each of the aspects of the current civil liability system. ${ }^{147}$

Suárez conceives restitution as the act through which an offense is brought to an end. ${ }^{148}$ All wrongs, strictly speaking, consist of a violation of the right to

144 Vid. Jan Hallebeek, "Unjust Enrichment as a Source of Obligation", Restitution Law Review 10 (2002): 92-99; "La formación de la idea de 'enriquecimiento injustificado' como concepto jurídico en la Escuela de Salamanca", in Enriquecimiento injustificado en la encrucijada, eds. P. del Olmo \& X. Basozabal (Navarra: Thomson/Aranzadi, 2017), 37-47; The Concept of Unjust Enrichment in Late Scholasticism (Nijmegen: Gerard Noodt Instituut, 1996), 47-107; James Gordley, "The Moral Foundations of Private Law", 1-24; The Jurists (Oxford: Oxford University Press, 2013), 82-111; Robert Feenstra, "Grocio y el derecho privado europeo", Anuario de Historia del Derecho Español 45 (1975): 605-622; Nils Jansen, Theologie, Philosophie und Jurisprudenz in der spätscholastischen Lehre von der Restitution (Tübingen: Mohr Siebeck, 2013), 1-187; Joe Sampson, The Historical Foundations of Grotius' Analysis of Delict (Leiden: Brill, 2018), 164-182; Wim Decock and Jan Hallebeek, "Pre-contractual duties to inform in Early Modern Scholasticism", Tijdschrift voor Rechtsgeschiedenis 78 (2010): 89-133; Wim Decock, "Law of Property and Obligations: Neoscholastic Thinking and Beyond", in The Oxford Handbook of European Legal History, eds. H. Pihlajamäki, M. Dubber \& M. Godfrey (Oxford: Oxford University Press, 2018), 611-631; Theologians and Contract Law. The Moral Transformation of the ius commune (ca. 1500-1650) (Leiden: Martinus Nijhoff, 2012), 494-604.

145 Thomas Duve, "La teoría de la restitución en Domingo de Soto", in La ley natural como fundamento moral y jurídico en Domingo de Soto, ed. Juan Cruz (Pamplona: Eunsa, 2007), 187. In the same work, Duve adds that “... neither in Roman Law nor in the subsequent tradition until the 16th century was there a 'system' of Law of Torts or Illicit Enrichment, not even a system that included all cases that generated the obligation to restitute a res in the broad sense of this concept".

146 Joseph Schumpeter, History of Economic Analysis (Abingdon: Routledge, 2009), 73-ss.

147 Gordley, "The Moral Foundations of Private Law", 1-24; José Barrientos, "La actio de in rem verso en la literatura jurídica francesa", Revista de Historia del Derecho Privado 3 (2000): 61-62.

148 Francisco Suárez, De bello (Über den Frieden. Über den Krieg) (Stuttgart: Frommann-Holzboog, 2013), s. VII, n. 2. 
property. Just as the Suárezian notion of illicit enrichment is very broad, so is the notion of property. We are not only the owners of external goods. We also have a (certain) right of ownership over honor, life, integrity, etc. As a result, Suárez understands corrective justice as a tool to protect the right of ownership or the right that acts as such, as mentioned in the previous section. Now, because restitution is a reparatory action -'a remedy' in terms of common law jurists-, it cannot be imposed on someone who has not inflicted any patrimonial or extrapatrimonial damage. The Spanish scholastics consider the existence of a real injury to the person or property of others the main requirement for the action for restitution. Therefore, Tomás de Mercado, one of the leading expositors on the Law of Contracts of the Scholastic tradition, maintains that restitution will not take place if no one has unfairly taken somebody's property. ${ }^{149}$

The restitution is deemed fulfilled even when the offender, against his will, compensates the offended, or when the debtor pays the creditor without wanting to do so. As Suárez writes,

Whoever performs an act $<$ such as the restitution $>$ without noticing it or against his will, is not obliged to do so again $[\ldots]<$ Thus, $>$ even if he does not want to, if the debtor restitutes, he will be free from the burden of repairing. On the other side, if the tithe has been paid or rather has been taken by force [...] one is not obliged to pay it again. Even if someone has given alms while drunk, his obligation ceases [...] As far as the duty to repay is concerned, it is important to know that it disappears $[\ldots]<$ not because a moral principle has been fulfilled, but because $>$ the debt has been extinguished, even if the debtor has been forced to pay, since $<$ as the classical writers have taught $>$ the will of the debtor is not always necessary for a debt to disappear. ${ }^{150}$

The Suárezian explanation is, one might say, that of strict positive law, since moral principles are not properly observed through an act which, although good before human law, is badly performed from the point of view of virtue. With Suárez's words, "although with a good act in itself, but badly performed, a natural law command can be fulfilled, that does not mean that the whole natural law is fulfilled [i.e. that one acts according to it]." ${ }^{151}$ The (right) intention required for accordance with moral norms is not required in positive human law, where the material performance of the due act suffices to extinguish the obligation. As a consequence, in the realm of human law -which cannot

149 Tomás de Mercado, Tratos y contratos de mercaderes (Salamanca: Mathias Gast, 1569), De restitutione.

150 De legibus ac Deo legislatore, 1. II, c. 10, n. 9.

151 De legibus ac Deo legislatore, 1. II, c. 10, n. 13. 
command every act of virtue or prohibit every single vice, and which is dictated for the average citizen-, the malice of the act of restitution spoils its legal rightness only when it is prohibited by the law itself. ${ }^{152}$

Aristotle, Suárez and the scholastics painstakingly define the nature and conditions of the commutative just in order to clearly differentiate illicit gains from justified acts of enrichment at the expense of another; in other words, not every juridically relevant enrichment stems from pleonexia. Current Civil Codes establish various hypotheses of 'justified' enrichment, such as the possibility that reciprocal benefits in a sale are not commutatively equivalent. This is not an innovation of Civil Law's modern jurists; unsurprisingly, this and other hypotheses of 'justified enrichment' were already advanced by the late scholastics. For instance, Suárez -who states that restitution will only be required when the enriched party cannot justify his conduct in any legal preceptexplains that a sale should cause no loesio enormis (i.e. the kind of contractual damage that jurists call 'lesion beyond moiety'), and that no contract should be sealed with fraud, force or another vice of consent.

Suárez did not write a unitary treatise on restitution, unlike other premodern scholastics. However, in contrast to other thinkers of his time, he mediated in a series of civil, political, canonical and economic lawsuits, many of which touch more or less directly on the issue of restitution. Among those arbitraments, gathered under the title Conselhos e pareceres, there is one in which Suárez must review a case of agnatic rights. That cannot be a coincidence. Suárez mostly examines the nature of restitution apropos the duties derived from filiation, which are not renounceable, as the Eximius repeats throughout his work. Indeed, on the basis of the principle of ius cognationis non posse repudiari, Suárez observes in De legibus ac Deo legislatore that the father must always restitute to his child the rights which he has unjustifiably denied to his offspring. ${ }^{153}$ The case I am referring to goes as follows:

A priest of good name and reputation had an illicit relationship with a dissolute and corrupt woman. She, however, was neither guarded nor watched by him at home, but enjoyed a shrewd, mendacious, and audacious liberty within his house. The presbyter had probable and reasonable motives to suspect that at

152 De legibus ac Deo legislatore, 1. II, c. 10, n. 13. “... this is what happens when a person receives communion unworthily at the Easter time: this communion is in no way contrary to ecclesiastical law, since the precept that is broken then -to worthily receive the communion- is not human but natural, and this is the only one that is broken then. On the contrary, the natural law that commands an honest act also commands that it be done virtuously, since this is in accordance with the judgment of reason. Then... when a natural precept is fulfilled with an evil act, the natural law itself is violated".

153 De legibus ac Deo legislatore, 1. I, c. 2, n. 5. 
that time the woman was sleeping with an adolescent student, with whom she had a closer and more frequent contact than what she confessed, saying that she did not do so with malicious intent. But the presbyter knew with moral certainty that they were lovers and that she intended to marry him. The woman conceived and gave birth on a date when the child could have been born to the presbyter or to the student [...] The presbyter was uncertain of the son's filiation, and wishing $[\ldots]$ to avoid the danger of revealing the fact and suffering infamy $[\ldots]$ he deceitfully took the son away from the mother and entrusted him to the care of the common income $<$ of the community $>$ so that he would be educated. ${ }^{154}$

The doubt about the filiation leads the interested parties to ask for clarification as to whether or not the presbyter is obliged to recognize the minor, despite the damage to his honor. Suárez's answer to this question is that the priest is not obligated to acknowledge the paternity over the child. ${ }^{155}$ Second here is the point of interest- Suárez is asked to establish whether the priest is obligated to return to the community the money he took from the 'common income' to meet the needs of the child. It is certainly an issue of 'difficult resolution', Suárez says. ${ }^{156}$ First of all, he notes, it will be necessary to determine whether the child's mother is poor or not. If she is poor, the priest is not bound to restitution, because the economic needs of the mother and child justify, hic et nunc, the use of another people's money. Were the mother rich, the priest would have to return to the community the money spent on the care of the minor, because there would not be any grave need allowing him to feel in real need. ${ }^{157}$

Let us suppose, for the sake of the argument, that the priest is indeed the father of the minor. If so, he may not disavow his maintenance duty, for the correlative right to receive nourishment is inalienable. The father acquires this duty through the filiation itself. Suárez affirms that filiation determines kinship relationships, from which a series of rights and duties arise that are based on nothing more than the fact of being a descendant of another by right of blood, adoption, institution, etc. ${ }^{158}$

The broad conception of unjust enrichment in the Aristotelian Scholastic tradition -and the corresponding rules of restitution- applies to very diverse cases. To name some examples, Suárez deals with the duty of restitution that

154 Francisco Suárez, "De filiatione dubia", in Francisco Suárez, Conselhos e pareceres (Coimbra: Universidade de Coimbra, t. I, 1948), 179-183.

155 De filiatione dubia, 183. “... I say that this person can have peace of mind because he is not obliged to acknowledge the child as his own nor to feed him as such".

156 De filiatione dubia, 180.

157 De filiatione dubia, 179-183.

158 De legibus ac Deo legislatore, 1. I, c. 2, n. 5. 
weighs on the ruler who has waged war without legitimate cause,${ }^{159}$ on a judge who condemned someone without attending to the minimum procedural guarantees, ${ }^{160}$ on the parties of a duel, on the workers who, under the pretext of receiving an unjust pay, secretly and without motive lay their hand on the goods of their lord. ${ }^{161}$ Finally, if we expand Suárez's line of thought to, for example, war, then, as the general rule of restitution demands, we must conclude that war can only be declared if there is a serious attack on the common good, that is, only if there is a real wrong/injury. ${ }^{162}$ This is the obvious inference, the only possible one, since, as it has been said, there is no obligation to restore when no harm has been caused to third parties.

\section{CONCLUSION}

Despite the restitutive tinge in the Aristotelian and Scholastic explanation of commutative justice, corrective justice transcends its remedial side. Those who have tried to reduce corrective justice to reparation-saying, for example, that the act of commutative justice is restitution- seem not to notice that the structural unity of the two modes of partial justice obliges us to explain both the positive/constructive aspect and the negative/reparatory dimension of these virtues. Having said that, my impression is that Aristotle's and the Scholastics' teaching on commutative justice does not limit the equalizing function of this virtue to restitution. Among the thinkers belonging to the Aristotelian Scholastic tradition, Francisco Suárez occupies a central place. The Suárezian writings, including those still unedited, account for the precise and sophisticated legal theory of this author, who underlines, among other aspects, the directive/ instituting -and not only reparatory- character of the cardinal virtue of justice.

The Aristotelian distinction between voluntary and involuntary commutations has been adopted by jurists of the stature of Gaius, whence it has been integrated in all systems of Civil Law coming from the Justinian Law. Thus, from the voluntary and involuntary synallagmas we proceed to the Roman obligations ex contractu and ex delicto, which are the bases of the current systems of civil liability.

159 De bello, s. II, n. 6; s. IV, n. 8.

160 De legibus ac Deo legislatore, $1 . \mathrm{V}, \mathrm{c} .11, \mathrm{n} .4$.

161 De bello, s. VII, n. 2.

162 "Not any cause is sufficient to justify war, but only a cause that is grave and proportionate to the damage of war. Because of that, it is against natural reason to infer very serious damages for a slight injury". Francisco Suárez, De charitate (Opera omnia, v. XII, Paris: Vivès, 1858), d. XIII, s. 4, n. 2. 
Restitution is a type of payment of what is due, to use Suárez's terminology. Any restitution supposes that the order of justice, which existed prior to the illicit enrichment of one party at the expense of another, has to be re-established. The idea of 'illicit gain' is fundamental for a correct understanding of the classical theory of restitution. According to this theory, any injury to third parties entails a sort of gain for the offender. Now, the idea of 'gain' ('illicit gain' or 'unjust enrichment') exceeds the economic field. For this reason, Aristotle, Aquinas, and Suárez apply the rules of restitution to diverse spheres such as honor, life, and physical integrity. In this sense, they defend a notion of 'illicit gain' that almost coincides with that of 'commutative injury'.

Finally, diorthotic (or commutative) justice promotes a corrective ideal not only because it directs the reparation of abuses that occur in a legal relationship or that originate a new synallagmatic nexus. This is one aspect of corrective justice, but it is not limited to this compensatory role. In many other cases, nay, in the majority of them, this virtue seeks to render 'correct', 'right', 'proportionate', the obligations of the contracting parties, who expect the ideal of equality of the commutative justice to be present already at the time of the conclusion of the agreement. As Suárez points out, a virtue that directs commutative relationships from the start and renders them equitable cannot be defined as purely restorative.

\section{BIBLIOGRAPHICAL REFERENCES}

\section{PRIMARY SOURCES}

Aquinas, Thomas. Sententia libri Ethicorum. Notre Dame: Dumb Ox Books, 1993.

—. Sententia libri Politicorum. Indianapolis: Hackett, 2007.

-. Summa theologice. New York: Benziger Bros, 1947.

Aragón, Pedro de. De iustitia et iure. Salmanticæ, 1590.

Araújo, Francisco de. Las leyes (1638). Pamplona: Eunsa, 2010.

Aristotle. Artis rhetorica. Cambridge/New York: Cambridge University Press, 2009.

—. De iustitia. Librorum deperditorum fragmenta. Berolini: W. de Gruyter, 1987.

—. De republica Atheniensium. New Jersey: The Lawbook Exchange, 2004.

-. De sophisticis elenchis. Cambridge/Harvard: Harvard University Press, LCL 400, 1955. 
-. Ethica Eudemia. Cambridge/New York: Cambridge University Press, 2013.

- Ethica Nicomachea. Translated by Terence Irwin. Indianapolis, Hackett, 2019.

-. Ethica Nicomachea. Translatio Roberti Grosseteste Lincolniensis: Recensio pura, XXVI 1-3/3. Edited by René Antoine Gauthier. Leiden/Bruxelles: Brill/Desclée, 1972.

- Aristotle's Ethics. Edited by Jonathan Barnes and Anthony Kenny. Princeton: Princeton University Press, 2014.

—. Magna moralia. Cambridge/London: Harvard University Press, LCL 287, 1935.

—. Topica. Cambridge/London: Harvard University Press, LCL 391, 1960.

- Nicomachean Ethics. Translated by Joe Sachs. Indianapolis: Focus/Hackett, 2011.

- Nicomachean Ethics. Edited by Sarah Broadie and Christopher Rowe. Oxford: Oxford University Press, 2002.

-. The Arabic Version of the Nicomachean Ethics. Edited by Anna A. Akasoy, Alexander Fidora and Douglas M. Dunlop. Leiden/Boston, Brill: 2005.

-. The Nicomachean Ethics. Translated by Harris Rackham. Cambridge/ London: Harvard UP, LCL 73, 1934.

-. The Nicomachean Ethics. Edited by Harold Henry Joachim and David Arthur Rees. Oxford: Clarendon Press, 1956.

Báñez, Domingo. De iure et iustitia decisiones. Salamanticæ, 1594.

Camerarius, Joachim. Ethicorum Aristotelis Nicomachiorum explicatio. Francofurti, 1628.

Cano, Melchor. De locis theologicis. Roma: Libreria Editrice della Vera Roma di E. Filiziani, 1900.

Carranza, Bartolomé de. Catechismo christiano. Madrid: BAC, 1972.

- De iustitia. Pamplona: Eunsa, 2003.

Corpus Christi, Mancio de. De iure et iustitia. Pamplona: Eunsa, 2013.

Gaius, Institutiones. Oxford: Clarendon Press, 1904.

Groot, Hugo de. De iure belli ac pacis. Indianapolis: Liberty Fund, 2005.

Justinian. Digesta Iustiniani Augusti. Berolini: Weidmannos, 1870.

Oñate, Pedro de. De contractibus in genere. Romæ: Ex Typographia Francisci Caballi, 1647.

Osma, Pedro de. Commentaria in Ethicorum libros Aristotelis. Salamanca: Universidad Pontificia de Salamanca, 1996.

Magnus, Albertus. In X Ethicorum. Paris: Vivès, 1891.

Mercado, Tomás de. Tratos y contratos de mercaderes. Salamanca: Mathias Gast, 1569.

Michael Ephesius. In IX Ethicorum. London: Bloomsbury, 2001.

—. In librum quintum Ethicorum. Berolini: Georgii Reimeri, 1901. 
Peña, Juan de la. De iustitia. Coimbra: General Library of the University of Coimbra, ms. 1852.

Plato. Symposium. New Haven/London: Yale University Press, 1991.

Pseudo-Aristotle. Economica. Cambridge/London: Harvard University Press, LCL 287, 1935.

Roa, Fernando de. Repetitio de justitia et injustitia. Salamanca: Universidad Pontificia de Salamanca, 2007.

Soto, Domingo de. De iustitia. Roma: Vatican Library, ms. ott. lat. 781.

—. De iustitia et iure. Madrid: IEP, 1967-1968.

Suárez, Francisco. "De filiatione dubia." Vol. 1 of Conselhos e pareceres, 179183. Coimbra: Universidade de Coimbra, 1948.

-. Commentarii in Ethica Aristotelis. Paris: Bibliothèque Nationale de France, cod. lat. $6775,1585$.

- De pace. De bello. Über den Frieden. Über den Krieg. Stuttgart: FrommannHolzboog, 2013.

—. De charitate. Opera omnia, v. XII. Paris: Vivès, 1858.

—. De iustitia Dei. Opera omnia, v. XI. Paris: Vivès, 1858.

—. De legibus ac Deo legislatore. Conimbricæ, 1612.

-. Defensio fidei. Conimbricæ, 1613.

—. Qucestiones de iustitia et iure. Freiburg: Herder, 1958.

—. Tractatus quartus. Opera omnia, v. IV. Paris: Vivès, 1856.

Veracruz, Alonso de la. De dominio infidelium et iusto bello. Ciudad de México: UNAM, 2007.

Vico, Giambattista. De universi iuris principio et fine uno. Amsterdam/Atlanta: Rodoni, 2000.

Vitoria, Francisco de. De iustitia: De restitutione. Stuttgart: FrommannHolzboog, 2017.

Zapata y Sandoval, Juan de. De iustitia distributiva et acceptione personarum. Madrid: CSIC, 2004.

\section{SECONDARY SOURCES}

Barker, Ernest. The Political Thought of Plato and Aristotle. New York: Dover, 1959.

Barrientos Grandón, Javier. "La actio de in rem verso en la literatura jurídica francesa." Revista de Historia del Derecho Privado 3 (2000): 61-62.

Basalenque, Diego. Historia de la provincia de San Nicolás de Tolentino de Michoacán de la orden de nuestro padre san Agustín. Ciudad de México: Jus, 1963. 
Bastit, Michel. "La diversité dans les Institutes de Gaius." Archives de philosophie du droit 23 (1978): 333-343.

Bien, Günther. "Aristotle on Justice (Book V)." In Aristotle's Nicomachean Ethics, edited by Otfried Höffe, 109-131. Leiden/Boston: Brill, 2010.

Brieskorn, Norbert. Rechtsphilosophie. Stuttgart: Kohlhammer, 1990.

Jansen, Nils. Theologie, Philosophie und Jurisprudenz in der spätscholastischen Lehre von der Restitution. Tübingen: Mohr Siebeck, 2013.

Chénedé, François. Les commutations en droit privé. Paris: Economica, 2008.

Coing, Helmut. Europäisches Privatrecht. Älteres Gemeines Recht (1500 bis 1800). München: Beck, 1985.

Copleston, Frederick. A History of Philosophy: Greece and Rome. New York/London: Image, 1993.

Despotopoulos, Constantin. "La notion de synallagma chez Aristote." Archives de philosophie du droit 13 (1968): 115-127.

—. Aristote sur la famille et la justice. Bruxelles: Ousia, 1983.

Decock, Wim. "Law of Property and Obligations: Neoscholastic Thinking and Beyond." In The Oxford Handbook of European Legal History, edited by Heikki Pihlajamäki, Markus Dubber and Mark Godfrey, 611-631. Oxford: Oxford University Press, 2018.

-. Theologians and Contract Law. The Moral Transformation of the ius commune (ca. 1500-1650). Leiden: Martinus Nijhoff, 2012.

Decock, Wim and Hallebeek, Jan. "Pre-contractual duties to inform in Early Modern Scholasticism.” Tijdschrift voor Rechtsgeschiedenis 78 (2010): 89-133.

Duve, Thomas. "La teoría de la restitución en Domingo de Soto." In La ley natural como fundamento moral y jurídico en Domingo de Soto, edited by Juan Cruz Cruz, 181-198. Pamplona: Eunsa, 2007.

Englard, Izhak. Corrective and Distributive Justice. Oxford/New York: Oxford University Press, 2009.

Escriche, Joaquín. Diccionario razonado de legislación y jurisprudencia. París: Librería de Rosa, Bouret y Cia., 1852.

Feenstra, Robert. "Grocio y el derecho privado europeo." Anuario de Historia del Derecho Español 45 (1975): 605-622.

Finnis, John. Aquinas. Oxford: Oxford University Press, 1998.

-. Natural Law and Natural Rights. Oxford: Oxford University Press, 2011.

García, Francisco. Tratado utilísimo y muy general de todos los contratos (1583). Pamplona: Eunsa, 2003.

Gierke, Otto von. "The Social Role of Private Law." German Law Journal 19/4 (2018): 1017-1116.

Gordley, James. "The Moral Foundations of Private Law." The American Journal of Jurisprudence 47/1 (2002): 10-13. 
—. The Jurists. Oxford: Oxford University Press, 2013.

Guzmán Brito, Alejandro. "Para la historia de la formación de la teoría general del acto o negocio jurídico y del contrato. IV: Los orígenes históricos de la noción general de acto o negocio jurídico". Revista de Estudios HistóricoJurídicos 26 (2004): 187-254.

Hallebeek, Jan. 'La formación de la idea de ‘enriquecimiento injustificado' como concepto jurídico en la Escuela de Salamanca." In Enriquecimiento injustificado en la encrucijada, directed by Pedro del Olmo García and Xabier Basozabal Arrue, 37-47. Navarra: Thomson/Aranzadi, 2017.

—. "Unjust Enrichment as a Source of Obligation." Restitution Law Review 10 (2002): 92-99.

-. The Concept of Unjust Enrichment in Late Scholasticism. Nijmegen: Gerard Noodt Instituut, 1996.

Hamburger, Max. Morals and Law. The Growth of Aristotle's Legal Theory. New York: Biblo \& Tannen, 1971.

Höffe, Otfried. Aristotle. Albany: State University of New York Press, 2003.

- Democracy in an Age of Globalisation. Dordrecht: Springer, 2007.

-. Gerechtigkeit. Eine philosophische Einführung. München: Beck, 2007.

—. Political Justice. Cambridge: Polity Press, 1995.

Honoré, Tony. Gaius. Oxford: Clarendon Press, 1962.

Irwin, Terence H. "Glossary." In Aristotle, Nicomachean Ethics, 361-403. Indianapolis: Hackett, 2019.

-. Aristotle's First Principles. Oxford: Clarendon Press, 2002.

Kaufmann, Arthur. Rechtsphilosophie. München: Beck, 1997.

Kirchmann, Julius H. von. Erläuterungen zur Nikomachischen Ethik des Aristoteles. Leipzig: L. Heimann's Verlag, 1876.

López Santa María, Jorge and Fabián Elorriaga de Bonis. Los contratos. Parte general. Santiago: Legal/Thomson, 2010.

MacIntyre, Alasdair. A Short History of Ethics. London: Routledge, 1998.

- Whose Justice? Which Rationality? Notre Dame: University of Notre Dame Press, 1988.

Martini, Remo. Diritti greci. Torino: Zanichelli, 2005.

Mausbach, Joseph and Gustav Ermecke. Katholische Moraltheologie. Die spezielle Moral: Der irdische Pflichtenkreis. Münster: Aschendorff, 1961.

Miller, Fred Dycus. Nature, Justice, and Rights in Aristotle's Politics. Oxford/New York: Clarendon Press, 1995.

Muinelo Cobo, José Carlos. La invención del derecho en Aristóteles. Madrid: Dykinson, 2011.

Pieper, Josef. The Four Cardinal Virtues. New York: Harcourt, Brace \& World, 1965. 
Pietro, Alfredo Gustavo di. Derecho privado romano. Buenos Aires: Depalma, 1999. Polansky, Ronald. "Giving Justice Its Due." In The Cambridge Companion to Aristotle's Nicomachean Ethics, edited by Ronald Polansky, 151-179. Cambridge/New York: Cambridge University Press, 2014.

Prisco, Giuseppe. Principii di filosofia del diritto sulle basi dell'etica. Napoli: Manfredi, 1872.

Ricken, Friedo. "Aristoteles und die moderne Tugendethik." In Gemeinschaft, Tugend, Glück, 127-139. Stuttgart: Kohlhammer, 2004.

Ross, David. Aristotle. London/New York: Routledge, 2005.

Sachs, Joe. Aristotle: Nicomachean Ethics. Indianapolis: Focus/Hackett, 2011.

Sampson, Joe. The Historical Foundations of Grotius' Analysis of Delict. Leiden: Brill, 2018.

Schiemann, Gottfried. "Synallagma." In Brill's New Pauly. Encyclopcedia of the Ancient World: Antiquity, edited by Hubert Cancik and Helmuth Schneider. Retrieved from http://dx.doi.org/10.1163/1574-9347_bnp_e1127030.

Schulz, Fritz. Classical Roman Law. Oxford: Clarendon Press, 1961.

Schumpeter, Joseph A. History of Economic Analysis. Abingdon: Routledge, 2009.

Soto, Luís G. Teoría de la justicia e idea del derecho en Aristóteles. Madrid/Barcelona: Marcial Pons, 2011.

Villey, Michel. Le droit et les droits de l'homme. Paris: PUF, 2016.

Weinrib, Ernest J. The Idea of Private Law. Oxford: Oxford University Press, 2012.

Williams, Bernard. The Sense of the Past. New Jersey: Princeton University Press, 2006.

Wöhrle, Georg, ed. The Milesians: Thales. Berlin: W. de Gruyter, 2014.

Wolff, Hans Julius. "Diritto greco, diritto tolemaico." Dike 16 (2013): 97-122.

-. "Greek Legal History: Its Functions and Potentialities." Washington University Law Review 2 (1975): 395-408.

- . "La structure de l'obligation contractuelle en droit grec." Revue historique de droit français et étranger 44 (1966): 569-583.

—. "The Origin of Judicial Litigation among the Greeks." Traditio 4 (1946): 31-87.

Zimmermann, Reinhard. The Law of Obligations: Roman Foundations of the Civilian Tradition. Oxford/New York: Oxford University Press, 1996.

Sebastián Contreras Aguirre

Facultad de Derecho

Universidad de los Andes, Chile

Álvaro del Portillo 12455

Las Condes, 7620001 Santiago de Chile (Chile) https://orcid.org/0000-0002-4517-5600 